\title{
Supplier Networks in the German Aircraft Industry during World War II and their Long-term Effects on West Germany's Automobile Industry during the "Wirtschaftswunder"
}

\author{
by \\ Jonas Scherner (NTNU Trondheim)/Jochen Streb (University of Mannheim)/Stephanie Tilly \\ (University of Bochum)
}

2013

Forthcoming in Business History

\begin{abstract}
Re-constructing the complex supplier network of the famous Ju 88 air armament program we show that outsourcing activities increased considerably in wartime Germany. The resulting inter-firm division of labour did not lead only to a quite effective protection of the German aircraft production against Allied air raids but also contributed to enormous labour productivity growth in most stages of the production process. Even though aircraft production was prohibited in post-war Germany, this supplier network survived and became the backbone of the most spectacular symbol of West Germany's economic rebirth: the automobile industry.
\end{abstract}

\section{Key Words}

Aircraft, Armament, Germany, Outsourcing, Second World War, Supplier Network 


\section{Introduction}

In 1985, Oliver E. Williamson published his seminal work "The Economic Institutions of Capitalism" in which he analyses the factors influencing a company's decision about whether to manufacture intermediate products itself or to procure them from specialized suppliers - the so-called make-or-buy decision. ${ }^{1}$ Since then, the analysis of outsourcing activities has played a prominent role in economics and business research. In historical research, however, outsourcing has received far less attention. Only recently, scholars started to examine outsourcing processes in history more thoroughly, focusing especially on war economies during World War II. ${ }^{2}$ Tetsuji Okazaki showed that the creation and expansion of a geographically widespread network of suppliers of special parts and machinery parts was crucial for the rapid growth of the Japanese aircraft production during World War II. ${ }^{3}$ In wartime Japan, intermediate goods delivered by upstream firms rather than capital or labour were the bottleneck factors of aircraft output. $^{4}$

In Germany, armament production rather stagnated during the early war period but then more than tripled between early 1942 and the summer of $1944 .^{5}$ This alleged discontinuous development was first explained by the so-called Blitzkrieg thesis. Scholars claimed that Hitler deliberately decided to under-mobilize the German armament industry in order to free up resources for producing consumption goods that were needed to maintain the German population's approval of the Nazi's antagonistic policies. Only after the military failures at the end of 1941 did German military planners acknowledge that they had to increase weapons productions considerably by assigning as many resources and workers to armament production as possible. ${ }^{6}$ Since the 1980 s, however, the validity of the Blitzkrieg thesis has been questioned by many scholars. On the one hand, historians failed to discover evidence which proves that Hitler went into war with a deliberate Blitzkrieg strategy. On the other hand, it became clear that the Nazis did not consciously under-mobilize the armament industry before 1942 but heavily invested in armament production in the early period of the Second World War. ${ }^{7}$ Overy and Müller therefore introduced the inefficiency thesis into the historiography of the German Second World War economy. ${ }^{8}$ They share the opinion that it was armament minister Albert Speer, who assumed office in February 1942, who was responsible for fostering German armament production by removing the major obstacles for productivity growth.

Scherner and Streb show that the positive evaluation of Speer's managerial capability might be misleading too because its empirical basis, e.g. the index of German armament production, has 
serious shortcomings. ${ }^{9}$ Speer's administration intentionally chose the first two months of 1942 , in which armament production was comparatively low, as the base of the index, in order to exaggerate its own achievements in the following years. Another deficiency arises from the fact that the index also included armament goods that were produced in occupied countries. As a result, the index of armament production might considerably over-state the volume of weapons produced within the traditional borders of Germany after 1941 and therefore also the discontinuity between the pre-1942 period and Speer's period of office. Reviewing the macroeconomic data with respect to German industrial investment, production, and productivity in the period from 1939 to 1944 , Tooze also sees no reason to draw a sharp distinction between the period before and after 1942, and therefore no logic to highlight the achievements under Speer. ${ }^{10}$ Budraß, Scherner and Streb support Tooze's interpretation on the basis of microeconomic data for the aircraft industry. ${ }^{11}$ First of all, they confirm traditional explanations of the German "armament miracle" by showing that about two thirds of aircraft manufacturers' continuous labour productivity growth ${ }^{12}$ resulted from an increase in total factor productivity that captures among other things the effects of learning-by-doing, economies of scale and change from cost-plus-contracts to fixed prices in procurement. ${ }^{13}$ More surprising is their finding that about one third of labour productivity growth of the companies involved in the final stages of aircraft production cannot be explained by these often-discussed factors but has to be directly attributed to outsourcing activities. Outsourcing as a means for productivity growth has been generally neglected by economic historians analysing the German war economy. A notable exception is Fear who observes that, during the war, a new type of industry organisation evolved in the Swabian aircraft industry: The aircraft fighter manufacturer Messerschmitt, one of the three large German producers of combat aircrafts in the Nazi period, became the centre of a network of more and more highly specialised suppliers. ${ }^{14}$

Even though these new findings help a lot to understand which economic factors caused the alleged armament miracles in the German (and Japanese) war economies, there are still many open questions: Which motives fostered outsourcing in the German aircraft production and generally in the German armament industries? Did only strict economic arguments - such as emphasized in Williamson's study - play a role, or can some additional factors be identified? How was outsourcing organized and how did it evolve over time? Which impact had outsourcing on labour productivity at all stages of the value added chain? 
To answer these questions we discuss first the contemporary motives for outsourcing. We will see that in addition to strict economic considerations further factors played a prominent role, such as the expectation that geographically dispersed production would make the German armament production less vulnerable against allied bombing than centralized manufacturing. In the following section, the supplier network of the JU88 - the most produced German bomber during World War II - will be analysed in detail. In this network, we can distinguish two types of outsourcing activities. The first type covers the outsourcing of components like wings or other intermediate products to specialized suppliers. The second type is characterized by a firm's decision to use the capacities of so-called sub-suppliers ("Unterlieferanten") to produce some share of its final production in external plants. We show that both types of inter-firm division of labour considerably increased over time, leading to a remarkable supplier network all over Germany and Europe. This did not only lead to a quite effective protection of the German aircraft production against Allied air raids but also contributed to labour productivity growth in most stages of the production process.

Finally, we look at the long-term effects of these outsourcing activities. Did the wartime evolution of inter-firm division of labour have a lasting effect on the German post-war economy? What happened with the many highly specialized suppliers after the war, when the gigantic aircraft industry was partly dissolved and aircraft production prohibited? Was there an intertemporal transfer of managerial knowledge about the organisation of inter-firm division of labour from the aircraft industry to other industries? Our evidence suggests that the experiences made during the war in aircraft production widened outsourcing activities in a technologically and economically related industrial sector which is the most spectacular symbol of West Germany's economic rebirth: the automobile industry. ${ }^{15}$ This process would mirror the Japanese development. Nishiguchi claims that the emergence of the Japanese supplier network during the Second World War can neither be explained by a specific national culture nor an already existing dualism between large core companies and small firms in the peripheral economy. ${ }^{16}$ Instead, given the limited capacities of the traditional Japanese armament producers, buildingup extended supplier networks was the only available way to increase national weapons production fast and considerably. In the post-war catching-up period, Japanese firms adhered to this new and efficient form of industry organization because of the fast growing demand for their civilian products like automobiles. German firms faced very similar business conditions both during and after the war. That is why the evolution and continuity of the German supplier network might have been driven by the same economic necessities than the Japanese one. ${ }^{17}$ 
However, the sudden excess demand for additional production capacity might be a necessary but not a sufficient condition for the occurrence of extended supplier networks. As an additional precondition, a strong structure of small and medium-sized firms probably has to exist which was definitely the case in inter-war Germany. ${ }^{18}$

To understand the similarities and differences between the war economies of Second World War combatants it might be necessary to look, first, at the underlying economic problems all countries had to deal with, and, secondly, at the particular national solutions each country found for these problems. Applying this research concept to an analysis of the business history of outsourcing activities in Britain and Germany yields a surprising result. Facing the problem how to meet the fast increasing demand for aircraft engines with limited own production capacities, in 1939, the leading manufacturer Rolls-Royce also decided to rely on subcontractors that concentrated on the manufacturing of engine parts. Among Rolls-Royce' supplier network were over 120 firms whose new machine tools needed to produce the components of the engine were provided by the government. ${ }^{19}$ In contrast, the American company Ford was able to produce the Rolls-Royce-designed engine without an extended supplier network. In this case, advanced mass-production technology made outsourcing activities apparently dispensable. ${ }^{20}$ The example of Ford might be representative for the American war economy as a whole. At least, Cullen and Fishback claim that, during the Second World War, "contracting (American) firms were generally large players in industry who were reluctant to subcontract to smaller firms except for the least profitable parts of the contract."21 After the war, both American and British manufacturers did not experience above-average postwar catching-up growth. In the 1950s, the average annual growth rate of GDP accounts for $8.8 \%$ in Japan and $8.2 \%$ in Western Germany but only $3.3 \%$ in the US and $2.8 \%$ in the UK. ${ }^{22}$ This rather moderate growth might explain why, in contrast to Japanese and German firms, American and British companies stuck or returned to the more traditional concept of highly integrated (automobile) factories.

\section{Motives for Outsourcing}

Today, we know that some branches of the German armament industry, especially those manufacturing complex armament goods such as tanks or aircrafts, outsourced intermediate goods to the metalworking and machinery sectors with increasing frequency during the Nazi period. ${ }^{23}$ Outsourcing as a deliberate strategy was first explicitly formulated and pushed through with the JU 88-program. Junkers' CEO Heinrich Koppenberg convinced in 1937 the 
air ministry (Reichsluftfahrtsministerium) to manufacture the bomber JU 88 in inter-firm division of labour claiming that economies of scale and an increase in technological standards of aircraft production should be expected by this re-modelling of the production organisation. ${ }^{24}$ The largest firm involved in this program, Junkers, produced in its various plants still all components of the Ju 88 aircraft, including the engines, while other and smaller aircraft manufacturers like ATG, Arado, Heinkel-Oranienburg, or Siebel concentrated on specific components and tasks, such as wings, fuselages, engine suspension, tail units, and final assembly. ${ }^{25}$ In contrast to these firms, the Mitteldeutsche Motorenwerke was not engaged in airframe manufacturing but only produced engines for the Ju 88 bomber. Junkers itself was vested with the right to act as a state agency. It organized the flow of raw materials and labour to the different firms involved in the Ju 88-program and was even allowed to interfere in their spheres of production. In order to enable the other firms to imitate its design and production methods, Junkers shared production know-how and also gave them technological support when needed.

The Ju 88-program which was finally established by air minister Hermann Göring in mid-1938, constituted one of the largest German armament projects and presented a major innovation in German procurement organization. The firms that were involved in the original plan of 1938 employed more than half of the German aircraft production workforce. Even in 1943, when the focal point of air armament had already shifted to fighters, the participants in the $\mathrm{Ju} 88$ programme still employed a third of the workforce. Between September 1938, when series production started at Junkers, and September 1944, when it was cancelled, some 14,000 Ju 88 bombers were built. Maybe most important, this program served as a role model for outsourcing activities in the production of other armament goods. In contrast to Budraß, Scherner and Streb, ${ }^{26}$ in the following, we do not limit our analysis to the aircraft manufacturers of the final production stages of the Ju 88-program but cover the complete value chain.

The political decision to support the deepening of the inter-firm division of labour across regions can also be understood as an answer to the failure of the originally preferred centralisation strategy. Before the war, armament production had been partly concentrated in central Germany because this area seemed to be out of the range of potential enemy aircrafts given their then-operating distance. ${ }^{27}$ Yet, after the war had started, the growing military demand for armament goods produced by the firms in central Germany soon exceeded their production capacities. The Nazi economic planners first thought that the resulting labour 
shortage at the central German production sites could be resolved by making use of workers of metalworking companies located in the Western border regions. Based on various regulations enacted in 1938 and $1939^{28}$ authorities commanded these workers to move and work at the armament firms in central Germany. ${ }^{29}$ But armament manufacturers were not at all satisfied with the performance of the "forced" German workers (Dienstverpflichtete). Allegedly, these workers tried to prove their incompetence in the hope that they would be released such they could return to their families. ${ }^{30}$ "Forced" workers were apparently also much more prone to sickness than "regular" workers. ${ }^{31}$ Not only the fact that they had to work in places far away from their families contributed to the workers' discontent but also that their earnings were in some cases lower than in their previous positions. ${ }^{32}$ Moreover, regional Nazi leaders of border regions complained about the lack of military orders and the rationing of raw materials for civilian production which threatened to shut down metalworking companies in these areas. These complaints, coupled with the unwillingness of the "forced" workers, led politicians to change to the new outsourcing strategy: At the end of 1939, Dr. Fritz Landfried, state secretary in the department of trade and industry ("Reichswirtschaftsministerium") promised in front of the members of the Reich chamber of commerce ("Reichswirtschaftskammer") to spread future procurement orders all over Germany in order to keep the medium-sized firms during war-time in business. What is more, he assured that he had already asked the large German armament firms to use small and medium-sized firms as sub-contractors. ${ }^{33}$ In practice, military planners tried to maintain the final assembly of armament production in central Germany while they agreed to the production of intermediate inputs (such as parts of weapons) in border regions thereby allowing the former "forced" workers to stay in their home town. ${ }^{34}$ Strategic reasons for outsourcing remained important during the Second World War. In 1940, for example, the foundry Rudolf Rautenbach, traditionally located in Solingen, established additional capacities in the Harz Mountains to hide them from air attacks. ${ }^{35}$ In 1943, the armament ministry instructed the firm Dürener Metallwerke to relocate its production of ammunition production and the rolling of light metal from Western Germany to Central Germany. ${ }^{36}$ Both firms were part of the Ju 88 supplier network.

We have seen that the Nazi government pursued the goal of decentralizing armament production within the traditional borders of Germany at the latest from 1939. In August 1940, the scope of the outsourcing strategy widened as Hermann Göring declared that the best way to use the firms' production capacities in the occupied countries was to engage them as subcontractors. ${ }^{37}$ The member firms of the Ju 88 supplier network became soon part of this 
internationalization process. The aircraft engines manufacturer Argus Motoren Gesellschaft, for example, subcontracted the production of components to firms in France. ${ }^{38}$ Often, a knowledge transfer from Germany to occupied or allied countries was a necessary precondition for international outsourcing activities. The firm Dürener Metallwerke agreed in 1940 to train and consult the management and the workers of the foreign firms Alfa-Romeo in Milan, Nordisk Aluminiumindustrie in Oslo, and Jugoslawische Stahl AG in Sarajewo. The source does not reveal whether the management of the Dürener Metallwerke was reluctant to share their production know-how with potential future competitors. As a compensation for the knowledge transfer, however, Dürener Metallwerke received 1.2 million RM from the foreign firms in $1940 .{ }^{39}$ Knowledge transfer also took place within Germany. The newly-founded manufacturer of airframe components Mansfeld-Werke $\mathrm{GmbH}$, for example, relied on the experience of its parent factory Christian Mansfeld. ${ }^{40}$

The Nazi government clearly pushed German armament manufacturers to outsource parts of their production program to domestic and foreign subcontractors. Without revitalizing the debate about the corporate freedom of action in the "Third Reich"41 we claim that the armament firms had good reasons to obey to this wish of the regime voluntarily. Facing the excess demand for armament goods firms had to choose between one of the three following alternatives. First, they could try to decline some of the actual orders. This strategy, however, came not only with the risk that military procurement agencies would disregard them when allocating future orders across armament firms but also meant that the firms had to forego the usually high profits of state-financed armament production. ${ }^{42}$ Second, armament firms could decide to build up additional production capacities by investing in new plants and machinery. This alternative had its shortcomings too. Often enough, firms were not willing to take the risk of investing in what they assumed would become excess capacity once the war had ended and, consequently, of little long-term value. ${ }^{43}$ The way out of these problems was to rely on the new third alternative: By outsourcing the production of intermediate and final goods armament producers could use underutilized capacities of firms from other industries, and at the same time avoid investments in capital goods which could be fully utilized only under the conditions of war. ${ }^{44}$

[Table 1 near here] 
The system of inter-firm division of labour allowed the integration of many small and medium sized companies, which had manufactured predominately or exclusively civilian goods before the war, into armament production. ${ }^{45}$ Thus, the originally small number of German armament firms increased considerably during the war, as shown in Table $1 .{ }^{46}$ There is some evidence that this increasing inter-firm division of labour lowered the average labour productivity in the German armament production temporarily. ${ }^{47}$ The new suppliers displayed some typical startup problems, such as the re-training of the workforce and the conversion of the production organization. The process of know-how transfer took also some time, and was probably less successful than contemporaries claimed. ${ }^{48}$ Yet, in the longer run, the inter-firm division of labour led to learning effects and the realization of economies of scale resulting in an increasing labour productivity. ${ }^{49}$ Both the evolution of the supplier network and the resulting effects on labour productivity will be analysed in detail for the complete value chain of the Ju 88-program in the following sections.

To conclude, we found a rich set of motives explaining the intensification of outsourcing activities during the Second World War. The military planners worried about the vulnerability of centralised production centres to aerial bombardment and, what is more, tried to use production capacities and workforces in Germany's peripheral economic regions and in the occupied countries efficiently. The private armament firms, first of all, wanted to avoid warrelated investment in excess capacities. The method to use small manufacturers in the immediate geographical neighbourhood as "extended workbenches" was clearly only a shortterm solution for wartimes. The outsourcing of components like wings or other intermediate products to specialized suppliers, however, had long-term effects because it provided the insight that this type of outsourcing might allow the realization of economies of scale and learning effects and therefore higher profits also in a peacetime economy. However, an intentional makeor-buy decision of the Williamson-type was not the starting point of the Firms' outsourcing activities in the German aircraft industry. Rather, it was after the supplier network was already established that firms learned about the economic advantages (and risks) that came along with outsourcing.

\section{The Supplier Network evolves}

To reconstruct the supplier network of the Ju 88-program we make use of the Federal Archives' large collection of audit reports the Deutsche Revisions- und Treuhand AG prepared for firms that were engaged in German armament production during the Second World War. ${ }^{50}$ The typical 
audit report contains not only a comprehensive analysis of the balance sheet and the profit-andloss account, but also detailed information about sales, prices, and costs. The reports - and this is crucial for the topic of this paper - often contain also lists both about important suppliers and the intermediate goods delivered by them.

We were able to identify the audit reports for 18 firms involved in the JU 88-program for which, with the exception of Eiso and Deutsche Industriewerke, supplier lists are available. These socalled primary firms cover all important production stages of aircraft production, from light metal production to final assembly. In Table 2, we distinguish between the firms involved in the final assembly and engine production (primary producers I) and the firms manufacturing aircraft frames and upstream products (primary producers II).

[Table 2 near here]

The primary firms' supplier lists contain the names of about 460 additional firms supplying special components or serving as "extended workbenches" 51 for the primary firms. We call this group of firms for which audit reports are not available the secondary firms of our network. To identify the important secondary firms we use the monetary value of the traded goods: All secondary firms that delivered at least five per cent of all intermediate inputs bought during an accounting year by at least one of the 18 primary firms are defined as important secondary suppliers. Using this selection criterion we find 77 important secondary firms. Table 3 shows the most important secondary suppliers ranked by their number of customers among the primary firms of the Ju 88-program. Obviously, most of the intermediate products supplied by these firms to aircraft manufacturers can also be used in the automobile industry. That is why these suppliers could easily change from civilian to armament production in wartime and back to civilian production in post-war Germany.

[Table 3 near here]

Note that we have only exact information about the bilateral supply relationships between the 18 primary firms and between the primary firms and the 77 important secondary firms, ${ }^{52}$ but not about those between the secondary firms and between the secondary firms and their tertiary suppliers. A fully re-constructed Ju 88-supplier network would also include the latter. However, our incomplete network already covers 277 bilateral supply relationships which form a complex 
network of inter-firm division of labour. The Allies learned late to attack the Achilles heel of this system of decentralized production: the transportation system. ${ }^{53}$ Compared to the primary producers, secondary producers were not concentrated geographically in the region between Berlin and Saxony, but were dispersed all over Germany. Foreign companies were part of the supplier network; among the important secondary firms we find, for example, Skoda in the Protectorate and the Norsk Aluminium Corp. in Norway. ${ }^{54}$

[Table 4 near here]

The audit reports of the Mitteldeutsche Motorenwerke (Mimo) and the Mansfeld-Werke both include the supplier list for five consecutive years thereby providing detailed insights in the evolution of these supplier networks over time.

[Table 5 near here]

As shown in Tables 4 and 5, in both cases, the number of suppliers increased significantly during the early years of the war. Since Mimo's supplier lists additionally distinguish between ready-to-install components (C) and further supplies (FS) as screws or half finished goods, we can observe that outsourcing activities grew especially in the first category. For example, the production of crank shafts that were traditionally manufactured by Mimo itself was outsourced to the Deutsche Edelstahlwerke. ${ }^{55}$ To make sure that the outsourced components were delivered in the required quality the outsourcing firms usually revealed their specific know-how, trained the supplier's workforce and helped to adjust its production method. ${ }^{56}$ All these findings support our view that the spreading of inter-firm division of labour was considerably accelerated by the outbreak of the Second World War. Obviously, companies focused on subsuppliers in the German region in which they were located, i.e. Mimo on firms in Saxony and Mansfeld-Werke on firms in Brandenburg and Berlin. Top-notch suppliers of intermediate goods were searched for and contracted all over Germany and in the occupied countries. For example, metalworking companies located in the region that today is known as North-RhineWestphalia played also an important role. The strong Western part of the aircraft network that also included traditional car makers like Opel, Daimler or BMW explains why it survived after the post-war German division the loss of those core aircraft manufacturers whose production sites were located in central Germany. 
[Table 6 near here]

The Gesellschaft für Luftfahrtsbedarf (GfL), founded in April 1938, had a very special role in the supplier network of the Ju 88-program. The original reason for the foundation of this state owned company was to reduce the high storage costs of the aircraft repair works which, to be prepared to make damaged aircrafts ready for battle again in short time, held large stocks of spare parts for all of the many German aircraft types. The GfL took over the procurement, financing and storage of these spare parts by building huge storage facilities closely located to important repair works. ${ }^{57}$ Table 6 shows that the GfL grew fast no matter whether measured by workforce, storage facilities, or sales. During this growth process the GfL became the intermediary between many small and medium-sized producers of aircraft components in Germany and occupied Europe, on the one hand, and the German aircraft manufacturers, on the other hand. In a world without modern telecommunications, the GFL established a simplified version of today's “just-in-time-production”. As a result, since 1941, the number of secondary firms directly supplying to the primary firms often stagnated or even decreased, as revealed in Tables 4 and 5. The abandonment of a direct bilateral supply relationship between two firms of the Ju88-network, however, did usually not imply the reduction of outsourcing activities because former direct suppliers now became indirect ones delivering via the intermediary GfL.

\section{Outsourcing, Price Reductions and Labour Productivity Growth}

The deepening of the inter-firm division of labour in the growing supplier network had a strong impact on the production structure of the individual firms which concentrated more and more on their respective core capabilities. This specialization process can be measured by the outsourcing ratio which is defined as the share of the expenses for intermediate goods in total production costs. Table 7 presents the development of the outsourcing ratios of the 18 primary firms of the $\mathrm{Ju} 88$-program. The outsourcing ratio of the aircraft engines manufacturer Mitteldeutsche Motorenwerke (Mi), for example, increased from only 20 per cent in 1937 to 68 per cent in 1943: While this firm initially produced many components of engines such as crank shafts in its own plants, it learned fast to rely on the intermediate goods delivered by upstream firms and to specialize on the assembly of engines.

It is clear from a theoretical perspective that the higher the number of different components of a particular good the higher is the potential to outsource parts of the production process. Displaying the average annual growth rate of the outsourcing ratio per production stage the last 
line of Table 7 supports this view. Outsourcing activities in the production stages final assembly, aircraft engines and components of airframes that all dealt with multiple parts and components were high whereas the production of rather simple goods like cylinder heads and screw threads (components of aircraft engines) or rolled and pressed goods from light metal offered hardly any opportunity for outsourcing.

[Table 7 near here]

The outsourcing activities depicted in Table 7 allowed both the manufacturers of the final products and the suppliers of the intermediate goods to realize economies of scale by concentrating on particular processes with high production volumes. Productivity gains especially resulted from the learning effects that occurred in long production runs. The more often a worker repeated a special task, the more efficient he or she became. Particularly, the working time needed to produce an aircraft was less with each successive unit of output (Alchian, 1963). In a competitive environment, firms would have been forced to lower their output prices according to these productivity gains. In this case, the increase in total factor productivity could easily be measured as the difference between the change in input prices and the change in output prices. ${ }^{58}$ Unfortunately, we cannot expect this clear-cut relationship between prices and productivity in the German armament market where oligopolistic or even monopolistic firms could use their information advantages to push through prices that were higher than their actual marginal costs. On the other hand, the German procurement agencies took every effort to detect decreasing production costs and force firms to lower their output prices appropriately. ${ }^{59}$ We can therefore assume that the historical changes in the output prices of the primary firms of the Ju 88-program mirror among other things the productivity gains resulting from their outsourcing activities.

[Figure 1 near here]

Figure 1 indeed suggests that the higher the annual growth of a firm's outsourcing activities the higher were the corresponding price reductions. Outliers are Rudolf Rautenbach with its anomalous sharp decrease in the outsourcing ratio of 20 per cent ${ }^{60}$ and Junkers Schönebeck with high annual price reductions of 27 per cent despite a comparatively low annual growth of outsourcing ratio of 5 per cent. 
In a second step, we use the historical output prices to calculate the development of firms' labour productivity defined as real output per blue-collar worker. Figure 2 shows that the empirical relationship between the annual growth rate of the outsourcing ratio and the annual growth rate of labour productivity is positive as supposed. The most noticeable outlier is here Siebel with a very high labour productivity growth. Especially, the firms Dürener Metallwerke and Rudolf Rautenbach confirm our hypothesis that in production stages with low outsourcing potential (Light metal, Components of Aircraft engines) labour productivity growth was also comparatively small. Note, however, that this is only a statistical correlation. Labour productivity could also have been affected by factors that were independent from the outsourcing activities like capital deepening or technical progress.

[Figure 2 near here]

Figure 3 summarizes the empirical results of this section. With the exception of the light metal sector every production stage of the value chain of the Ju 88-program realized both high reductions in output prices and remarkable labour productivity growth. Our analysis suggests that these changes were at least partly driven by firms' outsourcing activities and the economies of scale and learning effects coming along with outsourcing. Insofar, this paper strongly supports the most recent hypothesis that outsourcing is in fact an important factor when it comes to explaining the armament miracles of the Second World War. In addition, Figure 3 also implies that productivity gains added up along the value chain. If we look, for example, only at the maximum values of the upper value chain we see that the annual growth rates of labour productivity step by step increased from 18 per cent in light metal production via 51 per cent in manufacturing components of aircraft engines and 85 per cent in assembly of aircraft engines to $125 \%$ in final assembly of the $\mathrm{Ju} 88$ bomber. Even though the picture is less clear when we consider the whole range of firms' productivity growth rates in every production stage, this finding still suggests that the "miraculous" productivity growth in the German armament industry that has puzzled historians for a long time might have not primarily occurred in the prominent armament firms of the last production stage but rather along the value chain within the plants of many until-now-ignored suppliers.

[Figure 3 near here] 
It is reasonable to conclude that the managers of the various firms of the Ju 88 program learned to understand well the benefits of a complex supplier network. It seems therefore very likely that they tried to use the many inter-firm relationships deepened or even established during the Second World War for outsourcing activities in the post-war period. In the concluding section, we explore this hypothesis for the West German automobile industry.

\section{The Supplier Network survives}

The extraordinary economic prosperity in West Germany in the post 1945 era is closely related to the growth of the automobile industry. ${ }^{61}$ However, the impressive process of recovery and the ensuing "automobile boom" of the 1950s and 1960s has to be attributed to a large extent to the existence of a broader range of supplying companies providing parts and components, materials, intermediate goods and semi-finished products for the assembly of motor vehicles. Thus, the German carmakers - when meeting the demands of a rapid, catching-up motorization process - could draw on resources of these mostly small and medium-sized enterprises. ${ }^{62}$ The common effort of the carmakers and their suppliers paved the way for the emergence of a heterogeneous automotive network which later on was thought to be one of the characteristic features of the West German economy. ${ }^{63}$

Still, it seems important to consider that the roaring upturn of business, so puzzling in the view of many contemporaries, contained significant elements of continuity, since it unfolded_within structures which at least partially had been present before. Some of the basic threads of the vehicle construction net already existed in the interwar-period and inspired the building up of the technologically-related aircraft manufacturing network that was extended ${ }^{64}$ and refined under special circumstances during wartime. The continuity runs from car making to aircraft manufacturing and then back to car making. Interestingly enough, aircraft parts producers of Toyoda's wartime supplier network also became suppliers of auto parts in the post-war period. ${ }^{65}$ Whereas the preceding chapters analysed supply relationships and outsourcing processes in the German air armament industry (Ju 88-program) this section deals with supplier networks in the automobile industry after 1945. Given that automobile companies like the Daimler Benz AG and the Bayerische Motorenwerke $A G$ had been important actors in the air armament industry, this chapter focuses on the continuity of supply relations and outsourcing processes in the postwar automobile boom. The following concentrates on one aspect: the outsourcing process during the 1950s and 1960s. For the most part the narrative is now based on historical data 
stemming from business archives of the automobile industry (mainly Daimler Benz $A G$ ) and contemporary surveys.

Several parts- and component producers who had been active before the war and in the wartime-economy advanced to first-rate suppliers in the post-war boom. ${ }^{66}$ Companies like Robert Bosch GmbH (electrotechnical components), Alfred Teves $K G$ (brakes), $S K F$ Kugellagerfabriken GmbH, Kugelfischer Georg Schäfer \& Co. (bearrings), Deutsche Vergaser GmbH/Pierburg (carburator), Mahle (filter, piston) and VDO-Tachometerwerke GmbH (measuring instruments), most of which are also part of the Ju 88-supplier network, had worked with Daimler Benz since pre-war times and returned into business rather quickly. However, the change back to civilian production was not without adjustment problems. In May 1948, the management of the Daimler Benz $A G$ was alarmed due to the "urgent necessity to re-educate our suppliers". ${ }^{67}$ The minutes of the board meeting reveal that "the suppliers partially supply poor quality or, without asking us, make considerable modifications of the supplied parts." As a result, the CEO proposed to appoint somebody for the sole task "to educate the suppliers to impeccable supply" and to "bear down on the suppliers accordingly". 68

Although the positive wartime experience with supplier networks was still very vivid, the highly integrated automobile firm was still considered as the model path of production (Fordism). That is why, in the early post-war years, the smallest details could turn the balance back from "buy" to "make". "Whether Behr will supply reliably is doubtful. At first, buy coolers from Opel. I was on the verge of starting our own cooler factory at Sindelfingen. Behr is not reliable. He has let us down with air engine coolers." 69 This remark, uttered by the CEO of the Daimler Benz $A G$ in an executive staff meeting in July 1945, may give a hint on the situation the automakers felt to be in. On the one hand, they faced high uncertainty about the optimal makeor-buy decision; on the other hand, they wished to start business again as soon as possible. Despite these initial doubts, by 1958, the company Behr ranked among the top-notch suppliers with annual sales to Daimler of approximately 16.6 million DM. ${ }^{70}$

In search of a resumption of business relations, personal networks resulting from wartimes seemed to have played a significant role. The example of Carl Daniel Peddinghaus (CDP), a medium-sized company with about 500 employees, might be illustrative. ${ }^{71}$ The Westphalian family firm produced tools and, with rising importance, forged and pressed parts for the automobile and aircraft industry and for the state railway. ${ }^{72}$ During war-time, one of the 
directors, Günter Peddinghaus, worked in a task force of the ministry for armament and war production. Doing so, he was in charge of inspecting production sites in the forging industry, partially in the occupied regions, assessed their productive potential and worked out technical solutions. ${ }^{73}$ After his release from American war captivity, he was assigned - as a 'go-between' for the North German Coal Control $^{74}$ - to give advice to the administration on which drop forging factories should be reactivated in the British zone. His proposal focussed on 17 companies that seemed crucial to him as suppliers for the mining-, but also for the automobile industry. ${ }^{75}$ In the war-time economy, most of those firms had been represented in the "forging ring', a committee dealing with concerns of drop forging. ${ }^{76}$ Later on, these suppliers were part of the automotive network. Their connection would play an important role for the horizontal cooperation (i.e. coordination of competition and allocation of productive 'niches') within the supplying industries. ${ }^{77}$ By the end of 1945 several motor companies - Volkswagen, Vidal, Hanomag, Ford and Büssing - considered CDP as 'indispensable' for their production. ${ }^{78}$ Then, $C D P$ also succeeded as a supplier for the Daimler Benz $A G .{ }^{79}$ Most importantly, Peddinghaus achieved through his war-time contacts the status of a crucial, long-term supplier for Volkswagen: With the help of acquaintances made in the 'forging ring', who had good connections to the purchasing department at Volkswagen, the managers Günter and Theodor Peddinghaus could convince the motor company to abandon the plan of starting a in-house drop forge and to commit $C D P$ as first supplier. ${ }^{80}$ It seems plausible that after the war this use of war-time contacts for restarting business relations in the automobile industry became quite common. $^{81}$

In the middle of the 1950s, external procurement of finished and semi-finished products mounted up to about 50 to $60 \%$ of the production value of an automobile. ${ }^{82}$ Compared to other industries, the in-house-production-depth of the automobile industry was quite low: the "net quota', defined as the ratio between the net value (gross value minus the value of supplied intermediate goods) and the gross value of production, accounted for about $40 \%$ in 1958, in comparison to a quota of $47 \%$ in other industries. ${ }^{83} \mathrm{~A}$ couple of years earlier, the share of inhouse-production of the automobile industry had been higher - with a net quota adding up to nearly $50 \%$ in $1950 .{ }^{84}$ The decrease of this ratio throughout the $1950 \mathrm{~s}$ seems to indicate that outsourcing gained importance in the automobile industry in this period. This tendency could be explained by the rapid, above-average growth in automobile production. ${ }^{85}$ Facing a fast increasing demand for passenger cars the German automobile industry increased its production 
capacity also by outsourcing. After all, this strategy had already proven its value in a comparable situation during the armament boom in the Second World War.

Continuity cannot only be found with respect to the organisation of the inter-firm division of labour. Automobile manufacturers like Daimler Benz especially relied on suppliers that had already played a prominent role in the war economy. This fact may be illustrated on the basis of the important suppliers of the Ju 88-network (see Table 3), classified as "companies with the most customers".

[Table 8 near here]

Table 8 shows that, in the 1950s, all of these firms were part of the automotive network, eleven of them engaged as direct suppliers to the Daimler Benz $A G{ }^{86}$ The business volume those companies generated with Daimler Benz increased notably in this period. For example, the Kronprinz $A G$, supplier of wheels and precision tubes, multiplied the value of supplied goods to Daimler Benz eightfold; and in 1960 this amount added up to nearly 24.7 million DM. Table 9 reveals that Daimler Benz also maintained its business relations with 22 other important suppliers of the Ju 88-network. Moreover, one company of the former network, Auto-Union, was taken over by Daimler Benz in the late 1950s. In sum, Daimler Benz purchased upstream products from at least 35 companies which, during wartime, had ranked among the 91 important suppliers in the Ju 88-network. Given that in 1945 about 39 out of the 91 important Ju88suppliers were located east of the henceforward inner-German border (or were liquidated after 1945), the resumption quota was even higher: 35 out of 52 surviving companies in Western Germany had business relations with Daimler Benz in 1960. The supplier network of the former Ju 88-program had not only survived the war but prospered.

[Table 9 near here]

Yet, one should not jump to a conclusion regarding the future development of outsourcing in the post-war decades, because the tendency that gained contour in the 1950s cannot be interpreted as a general trend. With all due caution given some statistical problems, ${ }^{87}$ a cost structure analysis indicates that the share of expenses for material and finished products in the overall performance of the automobile industry decreased slightly from the mid-1950s to the mid-1960s. In 1967, it had fallen down to pre-war levels. ${ }^{88}$ A more detailed breakdown of the 
cost structure shows that the share of ready-for-assembly parts and components in the overall material costs decreased in comparison to the pre-war level, but did not vary significantly throughout the survey years 1954,1962 and $1967 .{ }^{89}$

In summary, it was especially the automobile industry's extraordinary growth in the 1950s that was backed-up by a growing supplier network. At the beginning of the 1960s, a new balance regarding the division of labour in the value chain of automobile production was established: A contemporary survey on that topic concluded that the in-house-production-depth of the German automakers by and large remained stable during the early 1960 s. ${ }^{90}$ An internal study about the Daimler Benz AG revealed that by 1963 the company did not have any plans to enlarge its in-house-production. For the time being, the management considered the status quo as "economically healthy". An increase of in-house-production was reserved to the rare cases in which the price calculations of suppliers exceeded significantly those of Daimler Benz. ${ }^{91}$

\section{Conclusions}

The strategy of outsourcing was crucial for both output and labour productivity growth in the German aircraft industry during the Second World War. Firms that were involved in most of the different production stages of aircraft production became more and more dependent from an increasingly complex network of suppliers, which included not only companies in the same region, but more and more suppliers in all of Germany and even in occupied countries. Productivity gains caused by economies of scale and learning-by-doing added up along the value chain. Consequently, the "miraculous" productivity growth in the German armament industry might have not primarily occurred in the prominent armament firms of the last production stage but rather along the value chain within the plants of many until-now-ignored suppliers.

The supplier network of air armament survived the end of the war: Many suppliers of the Nazi aircraft industry were again involved in the rise of the West German car industries during the 1950s. Wartime experiences and personal networks seemed to have played a significant role for re-starting business relations. Interestingly enough, like in the Japanese case discussed by Nishiguchi (1994), it was the fast increasing demand (for armament goods and passenger cars respectively) that triggered both in the Nazi armament industry and in the West German automobile industry, the deepening of the inter-firm division of labour. 


\section{References}

Abelshauser, Werner. Deutsche Wirtschaftsgeschichte seit 1945. Munich: C.H. Beck, 2004. Alchian, Armen. "Reliability of Progress Curves in Airframe Production." Econometrica 31 (1963): 679-693.

Bernstein, Jeffrey I., and David E. M. Sappington. "Setting the X Factor in Price-Cap Regulation Plans." Journal of Regulatory Economics 16, no. 1 (1999): 5-26.

Bernstein, Jeffrey R. "Toyoda Automatic Looms and Toyota Automobiles.“ In Creating Modern Capitalism, edited by Thomas K. McCraw, 396-438. Cambridge, MA: Harvard University Press, 1997.

Boelcke, Willi A. Die deutsche Wirtschaft 1930-1945: Interna des Reichswirtschaftsministeriums. Düsseldorf: Droste, 1983.

Botticelli, Peter. "Rolls-Royce and the Rise of High-Technology Industry." In Creating Modern Capitalism, edited by Thomas K. McCraw, 94-132. Cambridge, MA: Harvard University Press, 1997.

Buchheim, Christoph, and Jonas Scherner. "Corporate Freedom of Action - a Reply to Peter Hayes.“ Bulletin of the GHI 45 (2009): 109-112.

Budraß, Lutz. Flugzeugindustrie und Luftrüstung in Deutschland 1918-1945. Düsseldorf: Droste, 1998.

Budraß, Lutz, Jonas Scherner, and Jochen Streb. "Fixed-price Contracts, Learning and Outsourcing: Explaining the Continuous Growth of Output and Labour Productivity in the German Aircraft Industry during the Second World War." Economic History Review 63 (2010): 107-136.

Busch, Klaus. Strukturwandlungen in der westdeutschen Automobilindustrie. Berlin: Duncker \& Humblot, 1966.

Cullen, Joseph, and Price V. Fishback. "Did Big Government's Largesse Help the Locals? The Implications of WWII Spending for Local Economic Activity, 1939-1958." NBER Working Paper No. w12801, 2006.

Dickert, Elena: „Die Rolle der Auto Union bei der ,Nutzbarmachung` ausländischer Unternehmen. Auftragsverlagerung in die besetzten Gebiete während des Zweiten Weltkriegs.“ Zeitschrift für Unternehmensgeschichte 58, (2013): 28-53.

Diekmann, Achim. Die Automobilnachfrage als Konjunktur- und Wachstumsfaktor. Tübingen: Mohr, 1975.

Fear, Jeffrey. „Die Rüstungsindustrie im Gau Schwaben 1939-1945.“ Vierteljahrshefte für Zeitgeschichte 35 (1987): 193-216.

Geyer, Michael. „Zum Einfluss der nationalsozialistischen Rüstungspolitik auf das Ruhrgebiet.“ Rheinische Vierteljahrsblätter 45 (1981): 201-264.

Giersch, Herbert, Karl-Heinz Paqué, and Holger Schmieding. The Fading Miracle: Four Decades of Market Economy in Germany. Second ed., Cambridge: Cambridge University Press, 2005.

Hayes, Peter. "Corporate Freedom of Action in Nazi Germany." Bulletin of the GHI 46 (2009): 29-42.

Herrigel, Gary. Industrial Constructions: The Sources of German Industrial Power. Cambridge: Cambridge University Press, 1996. 
Klein, Burton H. Germany's Preparation for War. Cambridge, MA: Harvard University Press, 1959.

Milward, Alan S. The German Economy at War. London: University of London, Athlone Press, 1965.

Müller, Rolf Dieter. „Die Mobilisierung der deutschen Wirtschaft für Hitlers Kriegsführung.” In Das Deutsche Reich und der Zweite Weltkrieg 5/1: Organisation und Mobilisierung des deutschen Machtbereichs, Kriegsverwaltung, Wirtschaft und personelle Ressourcen: 1939. 1941, edited by Militärgeschichtliches Forschungsamt, 349-692. Stuttgart: Deutsche VerlagsAnstalt, 1988.

Neumann, Thomas. Carl Dan. Peddinghaus, Altenvoerde. Die Firmengeschichte zwischen 1919 und 1977. Ennepetal: Lüdenscheid Inst. für Geschichte und Biographie, 1996.

Nishiguchi, Toshihiro. Strategic Industrial Sourcing: The Japanese Advantage. New York: Oxford University Press, 1994.

Okamuro, Hiroyuki. "Evolution of the Supplier Network in the German Automotive Industry from the Prewar to Postwar Period: A Comparative Perspective with the Japanese Experience.” Business and Economic History On-Line (2004).

Okazaki, Tetsuji. "Supplier Networks and Aircraft Production in Wartime Japan.” Economic History Review 64 (2011): 973-994.

Overesch, Manfred. Bosch in Hildesheim 1937-1945. Göttingen: Vandenhoeck \& Ruprecht, 2008 .

Overy, Richard J. "The Luftwaffe and the European Economy 1939-1945."

Militärgeschichtliche Mitteilungen 26 (1979): 55-78.

Overy, Richard J. War and Economy in the Third Reich. Oxford: Clarendon Press, 1994.

Pega, Frank. Die Tätigkeit der Deutsche Revisions- und Treuhand AG von 1925 bis 1945. PhD Diss., LMU München, 2010.

Pesch, Martin. Struktur und Funktionsweise der Kriegswirtschaft in Deutschland ab 1942 unter besonderer Berücksichtigung des organisatorischen und produktionswirtschaftlichen Wandels in der Fahrzeugindustrie. Cologne: Müller Botermann, 1988.

Petzold, Inge. Die Zulieferindustrie: Betriebswirtschaftliche Untersuchung unter besonderer Berücksichtigung der industriellen Zulieferbetriebe zur Automobilindustrie. PhD Diss., Technische Universität Düsseldorf, 1968.

Scherner, Jonas, and Jochen Streb. „Das Ende eines Mythos? Albert Speer und das so genannte Rüstungswunder." Vierteljahrschrift für Sozial- und Wirtschaftsgeschichte 93 (2006): 172-196.

Scherner, Jonas. „Europas Beitrag zu Hitlers Krieg: Die Verlagerung von Industrieaufträgen der Wehrmacht in die besetzten Gebiete und ihre Bedeutung für die deutsche Rüstung im Zweiten Weltkrieg." In Europäische Volkswirtschaften unter deutscher Hegemonie, edited by Buchheim, Christoph, and Marcel Boldorf, 70-92. Munich: Oldenbourg Wissenschaftsverlag, 2012.

Scherner, Jonas. Die Logik der Industriepolitik im Dritten Reich: Die Investitionen in die Autarkie- und Rüstungsindustrie und ihre staatlichen Folgen. Stuttgart: Franz Steiner, 2008.

Scherner, Jonas: "Nazi Germany's Preparation for War: Evidence from Revised Industrial Investment Series." European Review of Economic History 14 (2010): 433-468. 
Scherner, Jonas, and Jochen Streb. „Wissenstransfer, Lerneffekte oder Kapazitätsausbau? Die Ursachen des Wachstums der Arbeitsproduktivität in den Werken der Deutschen

Sprengchemie GmbH, 1937-1943.“ Zeitschrift für Unternehmensgeschichte 53 (2008): 100122.

Speer, Albert. Erinnerungen. $9^{\text {th }}$ ed., Berlin: Propyläen, 1971.

Spoerer, Mark. Von Scheingewinnen zum Rüstungsboom: Die Eigenkapitalrentabilität der deutschen Industrieaktiengesellschaften 1925-1941. Stuttgart: Franz Steiner, 1996.

Stokes, Raymond G. Constructing Socialism: Technology and Change in East Germany 1945-1990. Baltimore: Johns Hopkins University Press, 2000.

Streb, Jochen. „Das Nationalsozialistische Wirtschaftssystem: Indirekter Sozialismus, gelenkte Marktwirtschaft oder vorgezogene Kriegswirtschaft?" In Der Staat und die Ordnung der Wirtschaft: Vom Kaiserreich bis zur Berliner Republik, edited by Plumpe, Werner, and Joachim Scholtyseck, 61-83. Stuttgart: Franz Steiner Verlag, 2012.

Streb, Jochen. "Negotiating Contract Types and Contract Clauses in the German Construction Industry during the Third Reich." The RAND Journal of Economics 40 (2009): 364-379.

Tilly, Stephanie. „Kooperation in der Krise? Beziehungspraktiken in der deutschen Automobilwirtschaft 1956-1979.“ In Automobilindustrie 1945-2000. Eine Schlüsselindustrie zwischen Boom und Krise, edited by Tilly, Stephanie, and Florian Triebel, 155-184. Munich: Oldenbourg, 2013.

Tilly, Stephanie. "Das Zulieferproblem aus institutionenökonomischer Sicht". Jahrbuch für Wirtschaftsgeschichte (2010): 137-160.

Tolliday, Stephen. "Enterprise and State in the West German Wirtschaftswunder: Volkswagen and the Automobile Industry." Business History Review 69 (1995): 273-350.

Tooze, Adam, and Christiano Ristuccia. "Machine Tools and Mass Production in the Armaments Boom: Germany and the United States, 1929-44." Forthcoming in Economic History Review 66 (2013).

Tooze, Adam. "No Room for Miracles. German Industrial Output in World War II Reassessed." Geschichte und Gesellschaft 31 (2005): 439-464.

Tooze, Adam: The Wages of Destruction: The Making and Breaking of the Nazi Economy. London: Allen Lane, 2006.

United States Strategic Bombing Survey. The Effects of Strategic Bombing on the German War Economy. Overall Economic Effects Division, October 31, 1945. Vol. 1. New York: Garland Publishing, 2006.

Van de Kerkhof, Stefanie. „Rüstungsindustrie und Kriegswirtschaft.“ In Was ist Militärgeschichte?, edited by Kühne, Thomas, and Benjamin Ziemann, 175-194. Paderborn: Schöningh, 2000.

VDA. Tatsachen und Zahlen aus der Kraftverkehrswirtschaft 1959/60. Frankfurt/Main: VDA-Wirtschafts-GmbH, 1960.

VDA. Tatsachen und Zahlen aus der Kraftverkehrswirtschaft 1961/62. Frankfurt/Main: VDA-Wirtschafts GmbH, 1962.

Wagenführ, Rolf. Die deutsche Industrie im Kriege, 1939-1945. Berlin: Duncker \& Humblot, 1954. 
Wellhöner, Volker. 'Wirtschaftswunder' - Weltmarkt - westdeutscher Fordismus. Der Fall Volkswagen. Münster: Westfälisches Dampfboot, 1996.

Werner, Stefanie, Harald Degner, and Mark Adamo. "Hitlers gläserne Arbeitskräfte. Das Arbeitsbuch als Quelle von Mikrodaten für die historische Arbeitsmarktforschung." Jahrbuch für Wirtschaftsgeschichte 52 (2011): 175-191.

Williamson, Oliver E. The Economic Institutions of Capitalism: Firms, Markets, Relational Contracting. New York: Free Press, 1985. 
Table 1: Armament producers in Germany, 1938-44

\begin{tabular}{llllllll}
\hline & 1938 & 1939 & 1940 & 1941 & 1942 & 1943 & 1944 \\
\cline { 2 - 8 } & & & & & & & \\
\hline
\end{tabular}

Source: 1938: Geyer, "Rüstungspolitik”, 256, Tab. 5. Data refer to March. Data for 1939 (end of the year) and 1940 (second half of the year) rely on information provided by 15 regional military procurement agencies (Rüstungsinspektionen). Data for 1941-44 rely on United States Strategic Bombing Survey, and were collected in June of the respective years. 
Table 2: Primary producers in the Ju 88-program

\section{Primary producers I}

Final assembley

\begin{tabular}{ll}
\hline Company & Main products \\
\hline
\end{tabular}

Siebel Flugzeugwerke GmbH, Halle a. d. Final assembly, wings

Saale (SI)

Weser Flugzeugbau GmbH, Bremen (WE) Final assembly Ju 87

\section{Aircraft engines}

Junkers Motorenbau Köthen (JK)

Junkers Motorenbau Magdeburg (JM)

Mitteldeutsche Motorenwerke GmbH, Leipzig

(MI)

\section{Components of aircraft}

engines

\begin{tabular}{|c|c|c|}
\hline & Argus Motoren Gesellschaft, Berlin (AR) & Aircraft engines, propellers \\
\hline & Askania Werke, Berlin (AS) & $\begin{array}{l}\text { Aircraft engine governors, optical } \\
\text { equipment }\end{array}$ \\
\hline & Eiso Schrauben GmbH, München (EI) & Precision screw threads \\
\hline & Rudolf Rautenbach, Solingen (RA) & Crank cases, cylinder heads \\
\hline & Vogtländische Metallwerke, Plauen (VO) & Propellers \\
\hline \multicolumn{3}{|l|}{ Primary producers II } \\
\hline \multicolumn{3}{|l|}{ Components of airframes } \\
\hline & Christian Mansfeld, Leipzig (CM) & Landing-gears \\
\hline & Deutsche Industriewerke, Berlin (DI) & Landing-gears, shock absorbing struts \\
\hline & Fritz Leitz, Oberkochen (LE) & Landing-gears \\
\hline & Junkers Schönebeck (JS) & Landing-gears, tail wheels \\
\hline & Mansfeld-Werke GmbH, Prenzlau (MA) & Landing-gears \\
\hline & Mechanik GmbH Rochlitz (Sachsen) (ME) & Hydraulic systems, pitch elevators \\
\hline \multicolumn{3}{|l|}{ Light metal } \\
\hline & Dürener Metallwerke AG, Berlin (DM) & Light metal, heavy metal \\
\hline & Leipziger Leichtmetallwerke, Leipzig (LL) & $\begin{array}{l}\text { Rolled and pressed products from light } \\
\text { metal }\end{array}$ \\
\hline
\end{tabular}

Aircraft engines

Aircraft engines, propellers, injection pumps

Aircraft engines 
Table 3: The most important suppliers in the Ju88-program

\begin{tabular}{llc}
\hline Company & Products & $\begin{array}{c}\text { Customers among } \\
\text { the primary firms }\end{array}$ \\
I.G. Farben, Frankfurt a. Main (Headquarter) & Light metal alloy & 10 \\
Dürener Metallwerke, Berlin ${ }^{\text {a }}$ & Tubes and rods & 9 \\
Vereinigte Deutsche Metallwerke, Frankfurt a. & Engine parts & 9 \\
Main (Headquarter) & & 8 \\
Deutsche Edelstahlwerke, Krefeld & Steel, crank shafts & 7 \\
Robert Zapp, Düsseldorf & Crank shafts & 7 \\
Schmidt \& Clemens, Berghausen & Steel, cast blanks & 6 \\
Kronprinz AG, Solingen & Shock absorbing struts, tail wheels & 6 \\
Rheinmetall-Borsig, Düsseldorf & Steel, light metal moldings & 5 \\
Elektron \& Co., Stuttgart & Pistons, landing-gear components & 5 \\
Robert Bosch, Stuttgart & Ignition plugs, engine parts & 5 \\
Vereinigte Leichtmetallwerke, Hannover & Sheet metal, tubes and rods & 5 \\
(Headquarter) & & 5 \\
Ruhrstahl AG, Witten & Steel, landing-gear components & 5 \\
\hline
\end{tabular}

Source: Various audit reports and own calculations.

a Dürener Metallwerke is the only primary firm in this list. 
Table 4: The evolution of the supplier network of the Mitteldeutsche Motorenwerke

\begin{tabular}{|c|c|c|c|c|c|c|c|c|c|c|}
\hline \multirow[t]{2}{*}{ Region } & \multicolumn{2}{|c|}{1938} & \multicolumn{2}{|c|}{1939} & \multicolumn{2}{|c|}{1940} & \multicolumn{2}{|c|}{1941} & \multicolumn{2}{|c|}{1942} \\
\hline & FS & $\mathbf{C}$ & FS & $\mathbf{C}$ & FS & $\mathbf{C}$ & FS & $\mathbf{C}$ & FS & $\mathbf{C}$ \\
\hline SH with & & 1 & & 2 & & 2 & & 2 & & 2 \\
\hline \multicolumn{11}{|l|}{ Hamburg } \\
\hline Lower & & & 1 & & 1 & & & & & \\
\hline \multicolumn{11}{|l|}{ Saxony with } \\
\hline \multicolumn{11}{|l|}{ Bremen } \\
\hline NRW & 3 & & 4 & 2 & 4 & 2 & 4 & 2 & 4 & 1 \\
\hline Hesse & & & 1 & & 1 & & 1 & & & \\
\hline Baden- & & & & & & & & 1 & & \\
\hline \multicolumn{11}{|l|}{ Württemberg } \\
\hline Bavaria & & & & 1 & & 1 & & 1 & & \\
\hline Thuringia & & & & & & 1 & & 1 & & \\
\hline Saxony- & & 1 & & 2 & & 1 & & 2 & & 1 \\
\hline Anhalt & & & & & & & & & & \\
\hline $\begin{array}{l}\text { Brandenburg } \\
\text { with Berlin }\end{array}$ & 1 & & 1 & 1 & & 2 & 1 & 4 & & 2 \\
\hline Saxony & & 1 & & 5 & & 7 & 1 & 5 & 1 & 2 \\
\hline SUM & 4 & 3 & 7 & 13 & 6 & 16 & 7 & 18 & 5 & 8 \\
\hline
\end{tabular}

Source: Audit reports for the Mitteldeutsche Motorenwerke. C means components, FS further parts. The suppliers' locations are assigned to actual German states. 
Table 5: The evolution of the supplier network of the Mansfeld-Werke

\begin{tabular}{llllll}
\hline Region & $\mathbf{1 9 3 8}$ & $\mathbf{1 9 3 9}$ & $\mathbf{1 9 4 0}$ & $\mathbf{1 9 4 1}$ & $\mathbf{1 9 4 2}$ \\
\cline { 2 - 6 } Schleswig-Holstein with Hamburg & & 1 & 1 & & 1 \\
Mecklenburg-Western Pomerania & & & & & 1 \\
Lower Saxony with Bremen & & 1 & 1 & 1 & 2 \\
North Rhine-Westphalia & 4 & 5 & 6 & 8 & 8 \\
Hesse & & & 2 & & 1 \\
Baden-Württemberg & 1 & 1 & 4 & 2 & 3 \\
Bavaria & & & 1 & & 2 \\
Saxony-Anhalt & 2 & 2 & 3 & 2 & 3 \\
Brandenburg with Berlin & 1 & 3 & 9 & 7 & 6 \\
Saxony & 1 & 2 & 4 & 5 & 5 \\
Silesia & & & & & 1 \\
Austria & & & & & 1 \\
SUM & $\mathbf{9}$ & $\mathbf{1 5}$ & $\mathbf{3 1}$ & $\mathbf{2 5}$ & $\mathbf{3 4}$ \\
\hline
\end{tabular}

Source: Audit reports for the Mansfeld-Werke.The suppliers' locations are assigned to actual German states and Austria. 
Table 6: The growth of the Gesellschaft für Luftfahrtsbedarf

\begin{tabular}{lllll}
\hline & $1939 / 40$ & $1940 / 41$ & $1941 / 42$ & $1942 / 43$ \\
\cline { 2 - 5 } Workforce & 534 & 2107 & 3876 & 3613 \\
Storage & 32 & 58 & 117 & 195 \\
facilities & & & & \\
Sales, m. RM & 3,1 & 127 & 1.240 & 1.460 \\
\hline
\end{tabular}

Source: Barch R 8135-5465. 
Table 7: Outsourcing ratios (in per cent) in the Ju 88-program ${ }^{\mathrm{a}}$

\begin{tabular}{|c|c|c|c|c|c|c|c|c|c|c|c|c|c|c|c|c|c|c|}
\hline & \multicolumn{2}{|c|}{$\begin{array}{c}\text { Final } \\
\text { assembly }\end{array}$} & \multicolumn{3}{|c|}{ Aircraft engines } & \multicolumn{5}{|c|}{$\begin{array}{c}\text { Components of aircraft } \\
\text { engines }\end{array}$} & & \multicolumn{5}{|c|}{ Components of airframes } & \multicolumn{2}{|c|}{$\begin{array}{l}\text { Light } \\
\text { metal }\end{array}$} \\
\hline & WE & SI & MI & JM & $\mathrm{JK}$ & $\mathrm{AR}$ & AS & VO & RA & EI & JS & ME & LE & $\mathrm{CM}$ & DI & MA & DM & LL \\
\hline 1937 & 35 & 34 & 20 & & 39 & & 29 & & & & & & & & & & 48 & \\
\hline 1938 & 34 & 43 & 41 & 46 & 45 & & 28 & 60 & & 15 & & & & & 46 & 35 & 43 & \\
\hline 1939 & 39 & 49 & 54 & 44 & 50 & 53 & 27 & 54 & & 10 & 31 & 22 & 36 & 32 & 43 & 27 & 44 & \\
\hline 1940 & 45 & 61 & 65 & 50 & 52 & 60 & 29 & 60 & 22 & 8 & 54 & 29 & 59 & 45 & 42 & 25 & 44 & 5 \\
\hline 1941 & 42 & 60 & 69 & 58 & 59 & 70 & 32 & 60 & 17 & 10 & 64 & 36 & 57 & 53 & 45 & 37 & 54 & 38 \\
\hline 1942 & 51 & 63 & 65 & 63 & 70 & 54 & 35 & 57 & & 11 & 69 & 43 & 67 & 56 & 42 & 46 & 41 & 38 \\
\hline 1943 & & 68 & 68 & & & 62 & 51 & & & & 62 & 48 & 73 & & 46 & & 45 & 44 \\
\hline $\begin{array}{l}\text { Average annual } \\
\text { growth rate }(\%)\end{array}$ & 9 & 17 & 39 & 10 & 16 & 4 & 13 & -1 & -20 & -7 & 26 & 28 & 28 & 25 & $\mathbf{0}$ & 8 & -1 & $9^{c}$ \\
\hline $\begin{array}{l}\text { Average annual } \\
\text { growth rate }(\%)\end{array}$ & & & & 21 & & & & $2^{b}$ & & & & & & 19 & & & & \\
\hline
\end{tabular}

\footnotetext{
a The outsourcing ratio is defined as the share of intermediate goods in total costs. Source: Various audit reports. For the abbreviations of company names see Table 2. Without Rautenbach (RA).

Without 1940.
} 
Table 8: Daimler's post-war business with the most important secondary firms in the Ju 88-program

\begin{tabular}{|c|c|c|}
\hline Company & $\begin{array}{l}\text { Business volume 1950, } \\
\text { in DM }\end{array}$ & $\begin{array}{l}\text { Business volume 1960, } \\
\text { in DM }\end{array}$ \\
\hline I.G. Farben, Frankfurt a. Main (Headquarter) ${ }^{\mathrm{a}}$ & & 27,626 (BASF 1955) \\
\hline \multirow[t]{2}{*}{ Dürener Metallwerke, Berlin } & 27,614 & 3,450,086 (Busch Jäger \\
\hline & & Dürener Metallwerke) \\
\hline Vereinigte Deutsche Metallwerke, Frankfurt a. & 479,973 & $3,163,435$ (1959) \\
\hline \multicolumn{3}{|l|}{ Main (headquarter) } \\
\hline Deutsche Edelstahlwerke, Krefeld & $2,037,233$ & $15,558,173$ \\
\hline Robert Zapp, Düsseldorf & 29,089 & 288.555 \\
\hline Schmidt \& Clemens, Berghausen & 25,754 & 145,269 \\
\hline Kronprinz AG, Solingen & $2,459,867$ & $24,681,283$ \\
\hline Rheinmetall-Borsig, Düsseldorf ${ }^{c}$ & & 66,701 \\
\hline Elektron \& Co., Stuttgart & & 504,162 \\
\hline Robert Bosch, Stuttgart & $10,230,078$ & $113,688,841$ \\
\hline Vereinigte Leichtmetallwerke, Hannover & 591,699 (VAW, & 2,074,550 (VAW, Bonn) \\
\hline${\text { (Headquarter })^{b}}^{b}$ & Grevenbroich) & \\
\hline Ruhrstahl AG, Witten & 689,128 & $8,691,788$ \\
\hline \multicolumn{3}{|c|}{$\begin{array}{l}\text { Source: Mercedes-Benz Classic Archive, Einkauf Lieferanten-Umsätze 1950, Lieferanten-Umsätze 1955, } \\
\text { Lieferanten-Umsätze 1960; Mercedes-Benz Classic Archive. Hitzinger 8, Vorstand Otto Jacob 1956-1963 } \\
\text { (“Lieferantenumsätze (über 1 Million), 1959”), October 3 }{ }^{\text {rd }}, 1960 .\end{array}$} \\
\hline \multicolumn{3}{|c|}{$\begin{array}{l}\text { Among the major successor companies of the } I G \text { Farben only BASF is mentioned as suppliers in the } \\
\text { files of the Daimler archives. In the } 1970 \text { s, however, Bayer AG became one of the most imprtant } \\
\text { suppliers of DB. }\end{array}$} \\
\hline \multicolumn{3}{|c|}{$\begin{array}{l}\text { b Among the succesors of this company was the Vereinigte Aluminium-Werke. } \\
\mathrm{c} \quad \text { The plant was used by Auto Union GmbH. }\end{array}$} \\
\hline
\end{tabular}


Table 9: Daimler's post-war business with the other important secondary firms in the Ju 88-program, located in Western Germany

\begin{tabular}{|c|c|c|}
\hline Company & $\begin{array}{c}\text { Business volume 1950, } \\
\text { in DM }\end{array}$ & $\begin{array}{c}\text { Business volume 1960, } \\
\text { in DM }\end{array}$ \\
\hline Alfred Teves & $3,361,271$ & $19,029,789$ \\
\hline Askania-Werke & - & 5,292 (in 1955) \\
\hline Bergische Stahl-Industrie & 195,622 & $1,634,183$ \\
\hline Carl Freudenberg & $\mathbf{5 1 8 , 5 3 5}$ & $4,627,133$ \\
\hline Deutsche Industriewerke & 65,917 & 911,311 \\
\hline Elektron \& Co. & - & 504,162 \\
\hline Fluggeräte Elma & 20,567 & - \\
\hline Gebr. Becker & - & $2,214,269$ \\
\hline Gesellschaft für elektr. Unternehmen & - & $7,199,717$ \\
\hline Hahn und Kolb & - & $7,125,330$ \\
\hline Hansa Metallwerke & - & 10,155 \\
\hline Honselwerke & - & $2,377,060$ \\
\hline Kammerich-Werke AG & $3,520,593$ & $11,807,962$ \\
\hline Langbein-Pfannhauser-Werke & 28,868 & 308,426 \\
\hline Mannesmann-Röhrenwerke & Verified & $1,395,135$ \\
\hline Ortlinghaus & - & 244,580 \\
\hline Pittler AG & - & $1,411,453$ \\
\hline Röchling & $\mathbf{8 5 9 . 8 3 7}$ & $7,342,925$ \\
\hline Rudolf Rautenbach & - & $1,204,245$ \\
\hline Schöller \& Bleckmann & - & 186,883 \\
\hline Siemens (various firms of the company group) & $1,358,669$ & $10,998,294$ \\
\hline W. und W. Schenk & - & 706,498 \\
\hline Wuppermetall GmbH & 39,947 & - \\
\hline
\end{tabular}

Source: Mercedes-Benz Classic Archive, Einkauf Lieferanten-Umsätze 1950, Lieferanten-Umsätze 1955, Lieferanten-Umsätze 1960; Mercedes-Benz Classic Archive. Hitzinger 8, Vorstand Otto Jacob 1956-1963 (“Lieferantenumsätze (über 1 Million), 1959”), October $3^{\text {rd }}, 1960$. 
Figure 1: Annual growth rates of outsourcing activities and output price reductions of the primary producers in the Ju 88-program

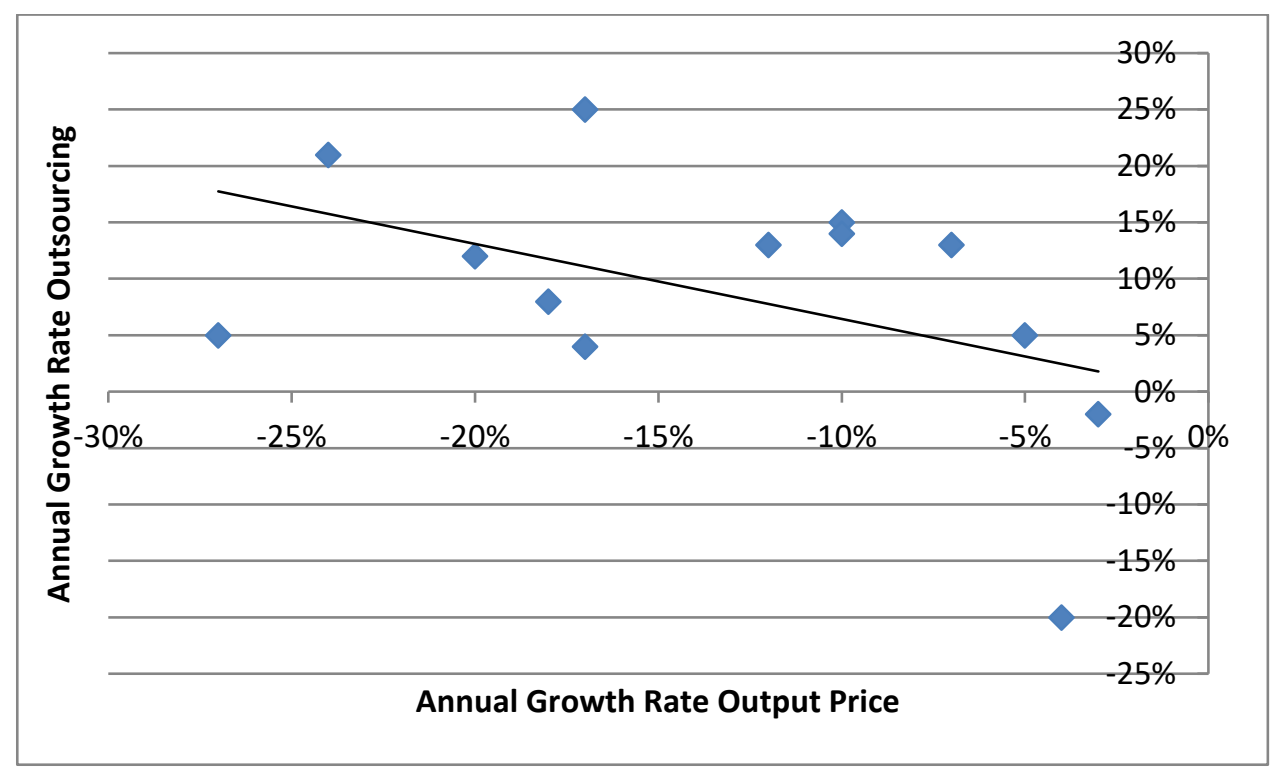

Source: Various audit reports and own calculations. Price data for Askania, Eiso, Fritz Leitz, Deutsche Industriewerke and Leipziger Leichtmetallwerke are not available. The correlation coefficient is -0,46. 
Figure 2: Annual growth rates of outsourcing activities and labour productivity of the primary producers in the Ju 88-program

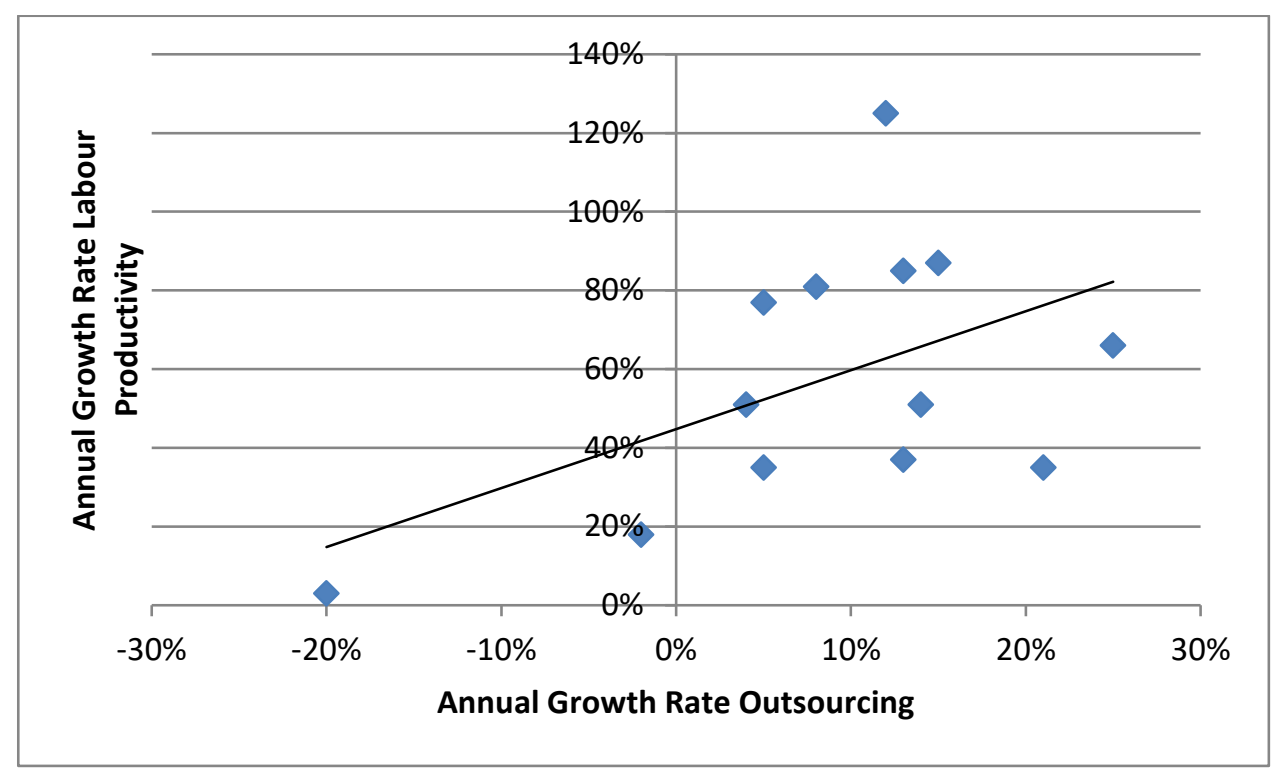

Source: Various audit reports and own calculations. Price and labour productivity data for Askania, Eiso, Fritz Leitz, Deutsche Industriewerke and Leipziger Leichtmetallwerke are not available.The correlation coefficient is 0,51 . 
Figure 3: Price reductions (italics) and labour productivity growth (bold) in the Ju 88value chain (annual growth rates)

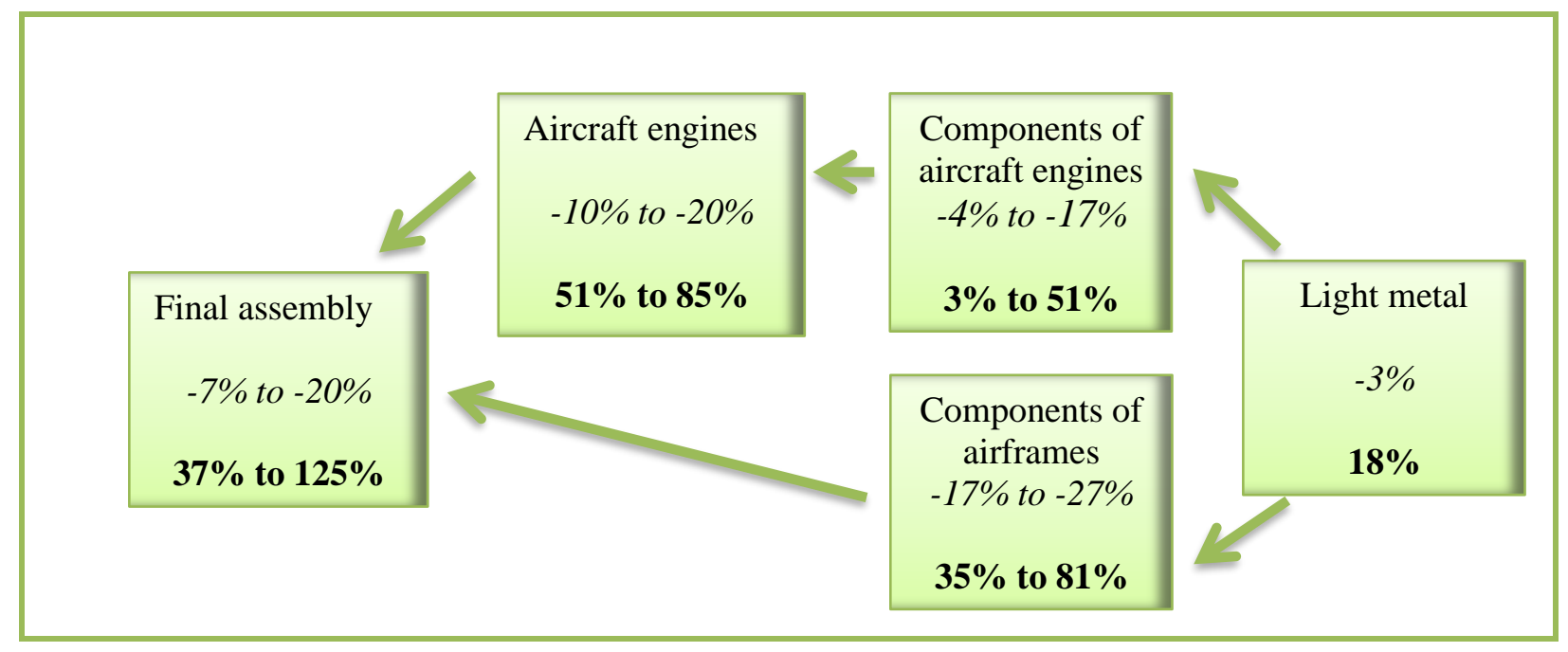

Source: Figures 1 and 2. See also Table 2. 
${ }^{1}$ Williamson, Economics of Capitalism.

${ }^{2}$ In 2000, van de Kerkhof was still right to criticize that economic historians neglected the suppliers of armament firms completely. Van de Kerkhof, "Rüstungsindustrie", 182.

${ }^{3}$ Okazaki, ,Supplier Networks“.

${ }^{4}$ Bernstein, "Toyoda Automatic Looms".

${ }^{5}$ Wagenführ, Deutsche Industrie, 178, 180.

${ }^{6}$ Klein and Milward were the most influential advocates of the Blitzkrieg thesis. Klein, Germany's Preparation for War; Milward, The German Economy.

${ }^{7}$ Scherner, "Nazi Germany's Preparation for War".

${ }^{8}$ Overy, War and Economy; Müller, "Mobilisierung".

${ }^{9}$ Scherner and Streb, "Das Ende eines Mythos".

${ }^{10}$ Tooze, "No Room for Miracles".

${ }^{11}$ Budraß, Scherner and Streb, "Fixed Price Contracts". These microeconomic data were collected from individual audit reports of the Deutsche Revisions- und Treuhand AG and are therefore not affected by the concerns one might have with (some of) the macroeconomic data that had been sugarcoated by Speer's ministry. For the activities of the Deutsche Revisions- und Treuhand AG see Pega , Deutsche Revisions- und Treuhand $A G$.

${ }^{12}$ Interestingly enough, labour productivity kept on growing despite the employment of more and more forced labourers. Apparently, German firms succeeded in replacing skilled labour with unskilled forced labour through investing in machine tools suitable for mass production. See Tooze and Ristuccia, "Machine Tools".

${ }^{13}$ For the changes in Nazis' price policy in procurement and construction see Streb, "Negotiating Contract Types".

${ }^{14}$ Fear, "Rüstungsindustrie".

${ }^{15}$ Stokes even implies that the initially quite innovative automobile Trabant, produced in the GDR since 1958, was a late outcome from the technological and organizational know-how accumulated in the production networks of Eastern Germany during war-time. The question whether the existing supplier networks were used or destroyed by the GDR authorities in the longer run has to be answered by future research. Stokes,

Constructing Socialism, 48.

${ }^{16}$ Nishiguchi, Strategic Industrial Sourcing, 34.

${ }^{17}$ Okamuro supports the view that the experiences with wartime aircraft production had a large influence on the evolution of the supplier networks in the post-war Japanese automobile industry. He observes, however, that the supplying firms were mostly not identical. Okamuro, "Supplier Network", 37.

${ }^{18}$ Herrigel, Industrial Constructions.

${ }^{19}$ Botticelli, "Rolls-Royce and the Rise of High Technology Industry", 114.

${ }^{20}$ Ibid., 115-118.

${ }^{21}$ Cullen and Fishback, "Big Government's", 11.

${ }^{22}$ Giersch, Paqué and Schmieding, Fading Miracle.

${ }^{23}$ See, for example, Bundesarchiv-Militärarchiv (hereafter BA MA) RW 19/561, note, 11.11.1939; fol. 11-3; note, 30.11.1939, fol. 3-8; RW 19/78, fol. 32; RW 20-3/9, fol. 94.

${ }^{24}$ Budraß, Flugzeugindustrie, 536-556.

${ }^{25}$ Budraß, Scherner and Streb, "Fixed-price Contracts".

${ }^{26}$ Ibid.

${ }^{27}$ In spring 1937, for example, General Leeb, head of the Heereswaffenamt, asked Bosch (based in Stuttgart) to set up in northern Germany a new, army-owned factory needed to manufacture starter motors and dynamos for German tanks. The Reichsstelle für Raumordnung (Reich office for environmental planning) suggested building this new factory east of the river Weser and north of the geographical line between Kassel and Leipzig in order to put it out of reach of British or French bombers. See Overesch, Bosch in Hildesheim, 40-95.

${ }^{28}$ See "Verordnungen zur Sicherstellung des Kräftebedarfs für Aufgaben von besonderer staatspolitischer Bedeutung" from June $6^{\text {th }}, 1938$, and from January $13^{\text {th }}, 1939$.

${ }^{29}$ For the regulation of the German labour market, see Werner, Degner and Adamo, "Gläserne Arbeitskräfte".

${ }^{30}$ BA-MA RW 19/1503, Die Probleme der deutschen Rüstungswirtschaft im Kriege, OKW WiRüAmt Stab,

Bearb.: Reg.Rat Dr. Tomberg., September 1940, fol. 99.

${ }^{31}$ BA-MA RW 20-3/13, fol. 143-4.

${ }^{32}$ See for example BA-MA RW 20-3/13, fol. 143-4.

${ }^{33}$ Boelcke, Deutsche Wirtschaft, 249.

${ }^{34}$ BA-MA RW 20/3-9, fol. 94. See also BA-MA RW 20/11-20, Geschichte der Rüstungsinspektion XI,

1.9.1939-30.9.1940, fol. 45.

${ }^{35}$ Audit report 1940, BArch R 8135-2473, p. 5. 
${ }^{36}$ Audit report 1943, Bundesarchiv Berlin-Lichterfelde (hereafter BArch) R 8135-7291, p. 4.

${ }^{37}$ Dickert, "Rolle der Autounion", 35.

${ }^{38}$ Audit report 1940, BArch R 8135-7095, p. 6.

${ }^{39}$ Audit report 1940, BArch R 8135-1339, p. 3.

${ }^{40}$ Audit report 1941, BArch R 8135-7690, p. 2.

${ }^{41}$ For this debate see Hayes, "Corporate Freedom" and Buchheim/Scherner, "Corporate Freedom". See also Streb, "Das nationalsozialistische Wirtschaftssystem".

${ }^{42}$ For the capacity constraints, see BA-MA RW 20-2/8, fol. 35; BA-MA RW 20-3/10, fol. 11; R 2501/15098,

Ansprache von Kurt Lange in Budapest, 8.6.1943, fol. 33; for the firms' problems to comply with military orders in time, see, for example, BA-MA RH 15/160, OKH, Denkschrift über die Steigerung der Munitionsfertigung auf Grund der Führerfertigung vom 12. Dez. 1939, fol. 262. For the high profits in armament production, see, for example, Spoerer, Von Scheingewinnen zum Rüstungsboom.

${ }^{43}$ Scherner, Logik der Industriepolitik.

${ }^{44}$ See, for example, the motives for the outsourcing decision of the Auto Union AG in Dickert, "Rolle der Autounion".

${ }^{45}$ See for example BA-MA RW 20-3/10, fol. 11-2.

${ }^{46}$ See for example BA-MA RW 20-11/20, Geschichte der Rüstungsinspektion XI, 1.9.1939-30.9.1940; fol. 19, $43-5,51$. Note that the regional military procurement agencies compiling the data captured not all of the suppliers before 1942. Notice also, that some of the new producers were so called "Mob" - firms which did not produce large volumes of armament goods before the war, but which were trained in manufacturing weapons in the late 1930s.

${ }^{47}$ Tooze, Wages of Destruction, 342.

${ }^{48}$ Scherner and Streb, "Wissenstransfer".

${ }^{49}$ Budraß, Scherner and Streb, "Fixed-price Contracts".

${ }^{50}$ Most of the still available audit reports cover the period from 1939 to 1943. Since the auditors needed at least one year to prepare their reports, most of the audits for the accounting years 1943/4 and 1944 are unfortunately missing and were probably never finished. The shelf mark of this collection held in the Federal Archives in Berlin is BArch R 8135.

${ }^{51}$ Junkers Schönebeck, for example, was forced to engage additional sub-suppliers in 1942/43 to meet its own production commitment. See audit report 1942/43, BArch R 8135-7577, p. 1.

${ }^{52}$ We have also data about the bilateral trade flows between the primary firms and all the rest of the secondary firms that supplied less than five per cent of a primary firm's intermediate inputs.

${ }^{53}$ Fear, "Rüstungsindustrie", 204.

${ }^{54}$ The Askania Werke, as another example, employed "extended workbenches" in Serbia. See audit report 1942, BArch R 8135-7099, p. 38.

${ }^{55}$ See appendix audit report 1941, BArch R 8135-7736, p. 23.

${ }^{56}$ An audit report for the Dürener Metallwerke reveals that this kind of knowledge was also transferred to foreign firms like, for example, Alfa-Romeo in Milan, Nordisk Aluminiumindustrie in Oslo, and Jugoslawische Stahl AG in Sarajewo. See audit report 1940, BArch 8135-1339, p. 3.

${ }^{57}$ BArch 8135/5465, Audit report GfL 1939/40.

${ }^{58}$ Bernstein and Sappington, "X-Factor".

${ }^{59}$ Budraß, Scherner and Streb, "Fixed-price Contracts"; Streb, "Negotiating Contract Types".

${ }^{60}$ Note that the data for Rudolf Rautenbach cover only the years 1940 and 1941 which might explain the unusual results.

${ }^{61}$ For the development of the German automobile industry during the "economic miracle" see, for example, Wellhöner, 'Wirtschaftswunder' and Tolliday, "Enterprise and State".

${ }^{62}$ There has not been much research concerning the economic history of the automotive suppliers so far. For a profound comparison of supplier relationships between pre-war-, wartime and post-war periods see Okamuro, "Supplier Network". See also Tilly, "Zulieferproblem". For a contemporary study see Petzold, Zulieferindustrie. ${ }^{63}$ Abelshauser, Deutsche Wirtschaftsgeschichte, 374.

${ }^{64}$ Some of the member firms of the Ju 88 supplier network were newly founded before the Second World War, like, for example, the Vogtländische Metallwerke or the Mansfeld Werke GmbH in 1937.

${ }^{65}$ Bernstein, "Toyoda Automatic Looms", 412.

${ }^{66}$ Okamuro, "Supplier Network".

${ }^{67}$ Mercedes-Benz Classic Archive, Protokolle der Vorstandssitzungen 1948, minutes of board meeting on May, $10^{\text {th }}, 1948$, p. 13. We would like to thank Wolfgang Rabus (Business Archives of Daimler AG) for the valuable help in finding data.

${ }^{68}$ Mercedes-Benz Classic Archive, Protokolle der Vorstandssitzungen 1948, minutes of board meeting on May, $10^{\text {th }}, 1948$, p. 13

${ }^{69}$ See the minutes of the meeting on July, 24th, 1945, Daimler Benz Archiv (hereafter DBA), Protokolle 19451947, 'LKW-Sitzung in Untertuerkheim', p. 28 (Dr. Haß̧8l). 
${ }^{70}$ DBA, Hitzinger 8, Note dated October3, 1960, ,Lieferumsätze (über eine Million) 1959.

${ }^{71}$ CDP was not a direct important supplier of the Ju 88 network, but presumably among the tertiary suppliers of the secondary firms.

${ }^{72}$ See business archives of CDP in Westfälisches Wirtschaftsarchiv (hereafter WWA), F 189.

${ }^{73}$ Compare Neumann, Carl Dan, $47 \mathrm{~s}$.

${ }^{74}$ WWA, F 189, file 121, vol. 2.

${ }^{75}$ The proposal dating from October, $27^{\text {th }}, 1945$ contained the following companies: Gebr. Halverscheidt, Voerde; Jung\&Sohn, Halver; Knippschild\&Beckmann, Hagen; Schöneweiss\&Co., Hagen; Gustav Tesche, Hagen; DEW, Remscheid; Walter Gott, Solingen; Rich. Abr. Herder, Solingen; Krumm\&Co. Remscheid; C.A. Schlemper, Solingen; Friedr. Hünninghaus, Gevelsberg; CDP, Altenvoerde;Eisenwerk Wanheim; Schmiedag, Hagen; Bochumer Verein; Brockhaus Söhne; Eisenwerk Rothe Erde; Siepmannwerke, Belecke. WWA, F 189, file no. 121, vol. 2 .

${ }^{76}$ The „Sonderring Gesenkschmiedestücke“ pertained to the „Hauptring“ „Iron and Steel“. For an organizational chart referring to November 1943 see WWA, F. 189, file no. 245. For the organization of committees related to the construction of motor vehicles and their reorganization see also Pesch, Funktionsweise der Kriegswirtschaft, 183ss., 194-201.

${ }^{77}$ Later on, Volkswagen disliked the strong connection between the several drop forging companies, because the motor company suspected them of price-fixing agreements, see Tilly, Kooperation in der Krise.

${ }^{78}$ See the correspondence in WWA, F 189, file 121, vol. 2, e.g. Julius Paulsen (purchasing department, Volkswagen) to Peddinghaus, November $11^{\text {th }} 1945$; Motor manufacturer committee, components and accessories industry to HQ British Administration O.R. on december, 14 $4^{\text {th }}, 1945$. See also Neumann, Carl Dan, 54.

${ }^{79}$ DBA, Hitzinger 8, Note dated October, 3rd 1960, Lieferantenumsätze (über 1 Million) 1959.

${ }^{80}$ Neumann, Carl Dan, 62. It is highly probable that the ,war-time contacts' mentioned here are Dr. Woldemar Gerhardt, leader of the 'Sonderring Gesenkschmiedestücke' (and representative of the Stahlwerke Röchling Buderus) and Heinrich Heuß, member of the working group 'motor vehicles' within the 'Sonderring Gesenkschmiedestücke, during war-time representative of the Adam Opel AG, but later on engaged at the purchasing department at Volkswagen. See the organization chart of the 'Sonderring Gesenkschmiedestücke' in WWA F 189, file no. 245 and correspondence between CDP, Volkswagen and friendly competitors in WWA, F 189, file no. 10 and file no. 273, therein 'Hausmitteilung', March $2^{\text {nd }} 1951$.

${ }^{81}$ The organizational chart of the mentioned 'forging committee' shows that staff of the automobile industry worked together with representatives of the supplying industry in several working groups. See WWA, F 189, file no. 245.

${ }^{82}$ Lippart, Werner. „Zubehör+Teile=1/2 Auto.“ Der Volkswirt, Beilage Kraftfahrzeugwirtschaft, 5 May 1956: 28-30.

${ }^{83}$ VDA, Tatsachen und Zahlen 1961/62, 256.

${ }^{84}$ Ibid., 259; Busch, Strukturwandlungen, 75. In 1936, this ratio came to about $45 \%$. Diekmann, Automobilnachfrage, 449.

${ }^{85}$ In the period from 1950 to 1958 the yearly production of the automobile industry quintupled: from a production of about 300.000 motor vehicles in 1950 to an output of approximately 1.5 million vehicles in 1958 (VDA, Tatsachen und Zahlen 1959/60, 30).

${ }^{86}$ See Mercedes-Benz Classic Archive, Hitzinger 8, Vorstand Otto Jacob 1956-1963 ("Lieferantenumsätze (über 1 Million), 1959”), October $3^{\text {rd }}, 1960$.

${ }^{87}$ Diekmann, Automobilnachfrage, 194.

${ }^{88}$ The quota added up to $58,5 \%$ (respectively $56,6 \%$ ) in 1962 and $55,8 \%$ (respectively $52,2 \%$ ) in 1967 . See different data series in Diekmann, Automobilnachfrage, 196, 223 and 449.

${ }^{89}$ Diekmann, Automobilnachfrage, 1975; VDA, Tatsachen und Zahlen 1961/62, 259.

${ }^{90}$ Bericht über das Ergebnis einer Untersuchung der Konzentration in der Wirtschaft vom 29. Februar 1964, erstattet vom Bundesamt für gewerbliche Wirtschaft in Frankfurt am Main, in: Deutscher Bundestag, IV. Wahlperiode, Drucksache IV 2320, p. 164.

${ }^{91}$ See Mercedes Benz Classic Archive, Werner Reich, Bericht über meine Untersuchung bei der Daimler-Benz $A G$, Stuttgart-Untertürkheim, without date, presumably 1963, p. 133p. 